\title{
Identifikasi penggunaan kata tidak baku pada merek dagang toko dan jasa di kota bengkulu
}

Tri Dina Ariyanti ${ }^{\mathrm{a}, 1^{\star}}$, Triesna Fuji Hatma ${ }^{\mathrm{b}, 2}$

a Manajemen, Ekonomi, Universitas Dehasen Bengkulu

b Informatika, Ilmu Komputer, Universitas Dehasen Bengkulu

tridina31@yahoo.co.id *; ${ }^{2}$ Iisfuji2015@gmail.com

*korespondensi penulis

\begin{tabular}{ll}
\hline Informasi artikel & \\
\hline Sejarah artikel: & \\
Diterima & $: 29$ Oktober 2019 \\
Revisi & $:$ I0 April 2020 \\
Dipublikasikan & $: 30$ April 2020 \\
\hline
\end{tabular}

ABSTRAK

Kata kunci:

Tujuan dalam penelitian ini adalah untuk mendeskripsikan kata tidak baku pada merek dagang dan toko di Kota Bengkulu. Metode yang digunakan dalam penelitian ini adalah deskriptif. Metode deskriptif dalam penelitian ini digunakan untuk mendapatkan pendeskripsian penulisan kata tidak baku pada merek dagang

Kata Tidak Baku, Merek Dagang toko dan jasa di Kota Bengkulu. Beberapa penulisan kata tidak baku yang didapat oleh penulis sudah menjadi sampel dalam penelitian ini diantaranya terdapat penulisan kata "photo copy", "antri”, "bis". Simpulan penelitian berdasarkan teori tentang ketidakbakuan ditandai dengan penyimpangan diantaranya:penggunaan kata, ejaan, dan susunan kalimat. Berdasarkan dari hasil penelitian yang diperoleh dan dikaitkan dengan teori ketidakbakuan didapat berupa kata dan ejaan. Hal ini dilihat dari para pemilik toko dan jasa menulis merek dagangnya tidak berdasarkan kata baku yang sudah ditetapkan dengan standar PEUBI (Pedoman Ejaan Bahasa Indonesia). Hasil dari penelitian ini didapat bahwa penulisan kata tidak baku masih terdapat di tempat-tempat umum, sehingga berdampak kepada masyarakat terutama pelajar, mahasiswa, para tokoh pendidik, dan lainnya adalah bahwa penulisan kata tidak baku masih terdapat di tempat-tempat umum, sehingga berdampak kepada masyarakat terutama pelajar, mahasiswa, para tokoh pendidik, dan lainnya.

Key word:

Kata Tidak Baku, Merek Dagang

\section{ABSTRACT}

The purpose of this research is to describe non-standard words in trademark brands and services in Bengkulu city. The method used in this research is descriptive. Descriptive method in this study was used to get the description of writing non-standard words in the trademark of shops and services in Bengkulu city. Some non-standard word writing obtained by the author has become a sample in this study including writing the words "photo copy", "antri", "bis". The discussion above found that the writing of non-standard words still exists in public places, therefore, it impacts on the community, especially students, educators, and others. The conclusion of the research is that the writing of non-standard words still exists in public places, so that it impacts the community, especially students, educative leaders, and others. The conclusions of the research based on the theory of incompetence are marked by deviations including: use of words, spelling, and sentence structure. Based on the results of research obtained and associated with the theory of non-standardization obtained in the form of words and spelling. This can be seen from the shop owners and their trademark writing services that are not based on standard words that have been set with the PEUBI standard (Indonesian Spelling Guidelines). The results of this study found that the writing of non-standard words still exist in public places, so that the impact on the community, especially students, students, educators, and others is that writing nonstandard words still exist in public places, so that the impact on society especially students, students, educators, and others.

Copyright (C) 2018 Universitas Ahmad Dahlan. All Right Reserved

\section{Pendahuluan}

Bahasa seringkali bersifat kabur serta majemuk dalam bentuk dan maknanya. Kekaburan dan kemajemukan itu terwuud baik dalam kalimat maupun dalam kata-kata sebagai unsur dasarnya. Hal ini merupakan salah satu kelemahan bahasa sebagai sarana komunikais ilmiah, karena ilmu menuntut persyaratan ketepatan sehingga bahasa ilmu pun harus tepat dan repdroduktif (Akhadiah, I9I:95). Kaidah tata bahasa berkaitan dengan masalah struktur kalimat, kaidah ejaan berkenaan dengan 
tanda baca, kaidah tata bunyi berkenaan dengan bunyi-bunyi fonem, kaidah komposisi berkenaan dengan pemilihan kata, kaidah kemaknaan berkaitan dengan kelogisan dan kenalaran dari makna kalimat (Rahardi, 2009: 136). Di samping tepat makna dan bentuknya. Kata-kata yang kita pergunakan hedaknya kata-kata yang baku. Karena pembakuan Bahasa Indonesia dalam bidang kosakata belum dilaksanakan, sampai saat ini belum ada pedoman yang baku dan tidak baku. Meskipun demikian, sampai batas-batas tertentu kata yang baku dan bukan yang baku contoh kata gadis itu baku sedangkan cewek bukanlah yang baku. Kata-kata dan ucapan hendaknya tidak dipergunakan contoh kata: dapet, malem, bener dan sebagainya (Soedjarwo, 2007: 92-93). Untuk menghindari kata-kata tidak baku maka perlu pengetahuan yang cukup untuk meyimpulkan penggunaan kata yang baku.

Ragam bahasa orang yang berpendidikan, yakni bahasa dunia pendidikan, merupakan pokok yang sudah agak banyak ditelaah orang. Ragam ini merupakan ragam yag kaidah-kaidahnya paling lengkap diperikan jika dibandingkan dengan ragam Bahasa lain. Ragam itu tidak saja ditelaah dan diperikan, tetapi juga diajarkan di sekolah. Sejarah umum perkembangan bahasa menunjukan bahwa ragam itu memperoleh gengsi dan wibawa yang tingi karena ragam itu juga yang dipakai oleh kaum yang berpendidikan dan kemudian dapat menjadi pemuka di berbagai bidang kehidupan yang penting. Pemuka masyarakat yang berpendidikan umumnya terlatih dalam ragam sekolah. Ragam itulah yang dijadikan tolok bandingan bagi pemakaian bahasa yang benar. Fungsinya sebagai tolok menghasilkan nama Bahasa baku atau bahasa standar baginya (Alwi, 2003: I3). Dalam teori yang telah dikemukakan, berbanding terbalik dengan masyarakat yang menggunakan sebagian kata dalam pengetahuan yang diperoleh dari melihat dan mendengarkan saja.

Sosok yang menunjukan bahwa dia adalah Indonesia, baik sebagai negara maupun sebagai bangsa, berwujud dalam dua kenyataan, yakni Bahasa Indonesia yang menampakkan diri sebagai identitas fonik dan merah putih serta Garuda Pancasila sebagai wujud fisik. Jika kita berada di luar negeri, lalu ada bunyi yang kita dengar, misalnya "oh kakiku” serta merta kita mengatakan, ia adalah orang Indonesia, tidak peduli apakah ia orang Batak, Dayak, atau orang Saparua. Demikian pula, kalau kita melihat sebuah gedung, lalu di sana berkibar bendera merah putih, dan di depan pintunya ada gambar garuda, kita dapat memastikan bahwa gedung tersebut adalah perwakilan Republik Indonesia. Hal yang sama, jika kita menyaksikan pasukan multibangsa, lalu ada pasukan yang baretnya ada pita kain merah putih, dan di dada atau di lengan anggota pasukan tersebut ada lambang garuda, kita dapat memastikan bahwa pasukan tersebut adalah pasukan Republik Indonesia. Dalam kaitan ini kita patut bangga kepada Presiden kita karena hamper dalam setiap kesempatan selalu menggunakan Bahasa Indonesia yang ternyata lebih memantapka identitas bangsa adalah pegaulan internasional (Muslich, 2010: 17).

Bahasa Indonesia sebagai lambang dan identitas nasional tidak luput dari tantangan. Meskipun bahasa Indonesia telah menjelma menjadi potensi budaya bangsa Indonesia, tantangan yang telah nyata sekarang, dan tantangan yang telah nyata sekarang, dan tantangan yang perlu diantisipasi harus dihadapi dengan perencanaan, pemikiran konseptual, intelektual, dan penuh kearifan. Tantangan itu ada yang bersifat internal dan ada yang bersifat eksternal. Tantangan yang bersifat eksternal itu, antara lain arus globalisasi. Tantangan pertama, yakni perkemabangan bahasa Indonesia yang dinamis, tetapi tidak menimbulkan pertentangan diantara masyarakat. Tantangan kedua, yakni persoalan tata istilah dan ungkapan ilmiah. Kedua tantangan tersebut dapat dikategorikan tantangan yang bersifat internal. Tantangan itu dapat dilihat dari kenyataan bahasa Indonesia itu sendiri, dan yang satu dari pemilik dan penutur bahasa Indonesia sendiri. Tantangan yang dating dari pemilik dan penutur bahasa Indonesia sebenarnya bersumber dari sikap, kesadaran berbahasa yang kemudian tercermin dalam perilaku berbahasa internasional (Muslich, 20I0: 20-2I).

Era globalisasi yang ditandai dengan arus komunikasi yang begitu dahsyat menuntut para pengambil kebijakan di bidang bahasa bekerja lebih keras untuk lebih menyempurnakan dan meningkatkan semua sektor yang berhubungan dengan masalah pembinaan bahasa (Muslich, 20I0: 6).Penggunaan bahasa Indonesia yang baik dan benar telah lama didengung-dengungkan oleh Pusat Pembinaan dan Pengembangan Bahasa. Lahirnya konsep bahasa Indonesia yang baik dan benar pada dasarnya tidak terlepas dari konteks pemakaian bahasa yang beragam, seperti bahasa yang baik dan benar (Putrayasa, 2007: 8I).

Menciptakan suatu komunikasi yang efektif dan efisien butuh usaha keras apalagi dalam penulisan sebuah kata agar mendapatkan pemahaman yang baik. Tanpa disadari, penulisanpenulisan yang terdapat pada tempat umum seperti di gedung-gedung baik merek dagang dan toko jasa lainnya tidak memenuhi aturan baku dalam tata bahasa Indonesia. Dalam hal ini, kesadaran lingkungan dalam bahasa tulisan masih belum 
disadari oleh masyarakat luas terutama pada bangunan-bangunan khususnya di Kota Bengkulu. Ketidaktahuan dan suatu kebiasaan dalam pelafalan sehari-hari dipergunakan oleh masyarakat pada umumnya merupakan dampak dari penulisan kata tidak baku tersebut.Jika sebuah kata tidak dipahami maknanya, pemakainnya pun mungkin tidak akan tepat. Hal itu akan menimbulkan keganjilan, kekaburan, dan salah tafsir. Penggunaan ketepatan pilihan kata ini dipengaruhi oleh kemampuan pengguna bahasa yang terkit dengan kemampuan mengetahui, memahami, menguasai, dan menggunakan sejumlah kosa kata secara aktif yang dapat mengungkapkan gagasan secara tepat sehingga mampu mengomunikasikannya secara efektif kepada pembaca atau pendengarnya (Widjono, 2007: 98).

Kata merupakan unsur bahasa yang diucapkan atau dituliskan, yang merupakan perwujudan kesatuan perasaan dan pikiran yang dapat digunakan dalam berbahasa. Dalam lingusitik, kata merupakan morfem atau kombinasi morfem yang oleh bahasawan dianggap sebagai satuan terkecil yang dapat diujarkan sebagai bentuk yang bebas (Sugihastuti, 2016: 188). Dalam bahasa manapun semua konsep dinyatakan dengan kata atau rangkaian kata. Kata merupakan salah satu unsur dasar bahasa yang sangat penting. Dengan kata-kata berpikir, menyatakan perasaan, serta gagasan. Memilih kata yang tepat untuk menyampaikan gagasan, teurtama melalui tulisan merupakan pekerjaan yang tidak mudah. Bahkan bisa dikatakan hal tersulit dalam proses penulisan (Rodiyah, 20II: I00).

Menyimak pemakaian Bahasa Indonesia baik dalam pembicaraan sehari-hari di kalangan masyarakat maupun dalam media massa belakangan ini meyakinkan kita bahwa berbahasa dengan baik dan benar belum dikuasai oleh sebagian besar masyarakat Indonesia. Ketika mendengar Bahasa Indonesia digunakan oleh masyarakat baik dalam percakapan sehari-hari maupun dalam situasi resmi. Bahkan tidak jarang hal ini di dengar melalui televisi dan radio. Demikian juga dalam media massa cetak masih terdapat penulisan yang salah. Kenyataan tersebut apabila tidak segera diusahakan perbaikannya jelas akan berakibat, tidak saja pemakaian Bahasa Indonesia tidak terkendalikan, melainkan juga akan melunturkan sikap budaya dan menggerogoti identitas bangsa Indonesia pada masa yang akan datang (Danardana,20I I: 43).

Pada penelitian sebelumnya dengan judul Penggunaan Bahasa pada Papan Nama di Ruang Publik Jalan Protokol Jakarta oleh Mutia Muqri, dkk (2016) membahas tentang Penggunaan bahasa pada papan nama ruang publik menggunakan satuan sintaksis tataran kata dan frasa sementara tataran klausa dan kalimat tidak ditemukan. Frasa merupakan satuan sintaksis yang paling banyak digunakan yaitu I52 data atau $92 \%$ data dari jumlah data I65. Tidak semua kategori frasa yang digunakan padapenamaan papan nama, hanya frasa nominal dan frasa adjektival saja yang digunakan sementara frasa verbal, frasa numeralial, frasa pronominal, frasa adverbial dan frasa preposisional tidak ditemukan penggunaannya. Frasa nominal merupakan bentuk penggunaan yang paling banyak digunakan yaitu I48 data dan frasa adjektival 4 data. Satuan sintaksis kata yang digunakan untuk penamaan papan nama berjumlah $\mathrm{I} 3$ data atau $8 \%$, dengan rincian kata sebanyak 7 data atau 4,3\% dan abreviasi sebanyak 6 data atau 3,7\%. Semua kelas kata yang digunakan berkategori nomina sementara kelas kata lain seperti verba, adjektiva, numeralia, pronomina, adverbia dan preosisi tidak ditemukan. Dalam penggunaan abreviasi, tidak semua jenis abreviasi digunakan pada penamaan papan nama hanya abreviasi bentuk singkatan 5 data dan akronim I data sementara abreviasi bentuk penggalan, kontaksi dan lambang huruf tidak ditemukan. Dalam hal ini penelitian oleh Mutia Muqri, dkk (2016) yang cakupan peneltiannya mendasari kepada penggunaan Bahasa dan wilayah yang diteliti wilayahnya luas. Hal ini, membedakan tentang penelitian yang berjudul Identifikasi Penggunaan Kata Tidak Baku pada Merek Dagang Toko dan Jasa di Kota Bengkulu dengan obyek yang diteliti adalah merek toko dan jasa yang masih menggunakan kata tidak baku.

Kata yang di populerkan melalui tulisan dalam penelitian ini terdapat pada papan nama merek dagang toko dan jasa yang seringkali dibaca dan dicerna oleh masyarakat contohnya ketika masyarakat berhenti di lampu merah sambil melihat dan membaca tulisan yang terdapat pada papan nama merek toko dan jasa. Kota Bengkulu tidak begitu luas cakupan wilayahnya. Dengan demikian, inormasi tidak begitu sulit untuk didapatkan. Informasi bisa saja didapat dari segi lisan dan tulisan. Kedua cara ini cukup bagi masyarakat untuk mendapatkan informasi baik valid ataupun tidak. Informasi tulisan bisa dilihat dari papan nama bermerek seperti di toko-toko dan jasa. Melalui media tulisan inilah masyarakat bisa menyimpulkan penulisan yang baku sedangkan penulisan pada papan nama terdapat di toko-toko merek dagang dan jasa khususnya di Kota Bengkulu tidak semuanya baku.

Maka, di Kota Bengkulu perlu adanya penjelasan secara rinci agar masyarakat tidak 
menyimpulkan berdasarkan hasil pengamatan saja penulisan-penulisan pada merek dagang toko dan jasa. Tujuan dalam penelitian ini adalah untuk mendeskripsikan kata tidak baku pada merek dagang dan toko di Kota Bengkulu. Rumusan masalah dalam penelitian ini adalah apa saja identifikasi penulisan kata tidak baku pada merek dagang dan toko di Kota Bengkulu. Adapun manfaat dari peneitian ini adalah untuk meningkatkan kesadaran penulis dan pembaca terutama kesalahan dalam menggunakan tulisan kata tidak baku khususnya secara tertulis. Dengan adanya penelitian ini dapat teridentifikasi penggunaan kata tidak baku pada merek dagang toko dan jasa di Kota Bengkulu.

\section{Metode}

Metode deskriptif merupakan metode penelitian yang berusaha menggambarkan dan menginterpretasi objek sesuai dengan apa adanya (Sukardi, 20II: I57). Metode yang digunakan dalam penelitian ini adalah deskriptif. Metode deskriptif dalam penelitian ini digunakan untuk mendapatkan pendeskripsian penulisan kata tidak baku pada merek dagang toko dan jasa di Kota Bengkulu. Data adalah hasil pencatatan peneliti, baik yang berupa fakta ataupun angka. Data adalah segala fakta dan angka yang dapat dijadikan bahan untuk menyusun suatu informasi (Arikunto, 2010: I6I). Data dalam penelitian ini berupa penulisan kata tidak baku pada merek dagang toko dan jasa di Kota Bengkulu. Sumber data dalam penelitian adalah subjek dari mana data dapat diperoleh. Apabila peneliti menggunakan kuesioner atau wawancara dalam pengumpulan datanya, maka sumber data disebut responden, yaitu orang yang merespon atau menjawab pertanyaan-pertanyaan peneliti, baik pertanyaan peneliti, baik pertanyaan tertulis maupun lisan (Arikunto, 20I0: 172). Sumber datanya adalah penulisan kata tidak baku yang terdapat pada penulisan merek dagang toko dan jasa di Kota Bengkulu.

Metode dokumentasi yaitu mencari data mengenai hal-hal atau variabel yang berupa catatan, transkip, buku, kamus PEUBI dan sebagainya. Dibandingkan dengan metode lain, maka metode ini agak tidak begitu sulit, dalam arti apabila ada kekeliruan sumber datanya masih tetap, belum berubah. Dengan metode dokumentasi yang diamati bukan benda hidup tetapi benda mati (Arikunto, 2010: 274). Teknik yang digunakan untuk mengumpulkan data dalam penelitian ini dokumentasi. Langkah-langkah pengumpulan data yaitu (I) Observasi bangunan yang bertuliskan merek dagang toko dan jasa yang tidak baku terdapat di Kota Bengkulu: (2) Mencatat dan mengambil gambar tulisan kata tidak baku pada merek dagang toko dan jasa di Kota Bengkulu: (3) Menandai dan memilih tulisan tidak baku pada merek dagang toko dan jasa di Kota Bengkulu.

Adapun analisis data penelitian ini sebagai berikut: I) Mengklarifikasikan penulisan kata tidak baku yang telah didapat dari lapangan (2) Menggambarkan penulisan kata tidak baku dan memperkirakan penyebab kesalahan penulisan (3) Mengoreksi kesalahan penulisan kata tidak baku dan memperbaiki kesalahan dalam penulisan

\section{Hasil dan Pembahasan}

Penemuan kata tidak baku sebagian banyak masih terdapat pada tempat terbuka yang mudah dilihat oleh masyarakat. Penulisan kata perlu diketahui secara baik dan benar agar tidak selalu diikuti dan ditafsir salah oleh masyarakat.Dengan demikian, menjadi permasalahan bersama dalam memberikan kejelasan untuk diperbaiki ke depannya dan tidak terjadi kesalahan-kesalahan dalam penulisan. Untuk itu, perlu diketahui secara jelas perbedaan kata baku dan kata tidak baku yang harus digunakan untuk dipedomani. Dalam menganalisis kata tidak baku ini melihat Pedoman Ejaan Umum Bahasa Indonesia atau yang dikenal dengan Ejaan yang Disempurnakan. Berikut di bawah ini merupakan data didapat dari lapangan yakni penulisan kata tidak baku:

Tabel I. Kata Tidak Baku pada Merek Dagang Toko dan Jasa di Kota Bengkulu

\begin{tabular}{cll}
\hline No. & \multicolumn{1}{c}{$\begin{array}{c}\text { Nama Merek } \\
\text { Dagang }\end{array}$} & Jenis Kata \\
\hline I. & Praktek & Tidak Baku \\
2. & Jam & Tidak Baku \\
3. & Jumat & Tidak Baku \\
4. & Photo Copy & Tidak Baku \\
5. & Antri & Tidak Baku \\
6. & Tehnik & Tidak Baku \\
7. & Electronic & Tidak Baku \\
8. & Bis & Tidak Baku \\
9. & Senen-Jumat & Tidak Baku \\
I0. & Berkwalitas & Tidak Baku \\
I1. & H, Sulaiman & Tidak Baku \\
I2. & Matrai & Tidak Baku \\
13. & Abank Rangga & Tidak Baku \\
I4. & Central Poncel & Tidak Baku \\
I5. & & Tidak Baku \\
\hline
\end{tabular}


Sate Ati dan Sate

Ucus

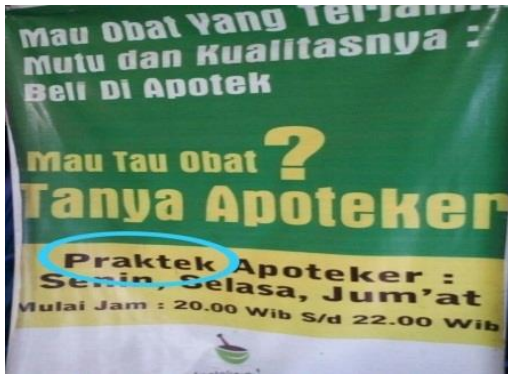

Penulisan kata "praktek" pada gambar di atas terdapat pada spanduk di sebuah bangunan. Tulisan "praktek" merupakan kata tidak baku yang seharusnya "praktik". Penulisan kata tidak baku ini biasanya dilafalkan dalam kehidupan sehari-hari. Dengan demikian, dari pelafalan menjadi suatu kebiasaan dan akhirnya dalam penulisan pun dibuat dengan tidak berpedoman Kamus Besar Bahasa Indonesia.

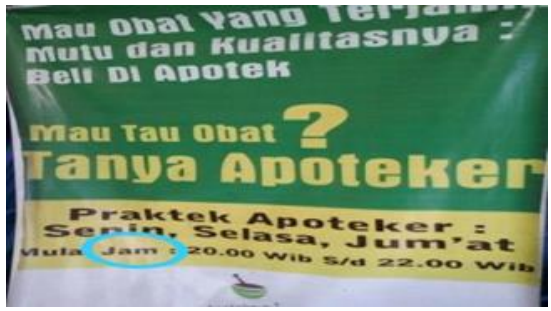

Kata "jam” menunjukan berapa lama waktu perjalanan. Masyarakat terbiasa menyebutkan jam adalah menunjukan waktu. Hal ini secara jelas dalam beberapa teori yang terdapat pada beberapa buku yang ditulis oleh ahli bahasa bahwa "jam" bakunya adalah "pukul". Jam adalah berapa waktu yang digunakan dalam proses misal seseorang berangkat dari pukul 07.00 sampai pada 09.00, jarak antara kedua pukul tersebut adalah dua jam.

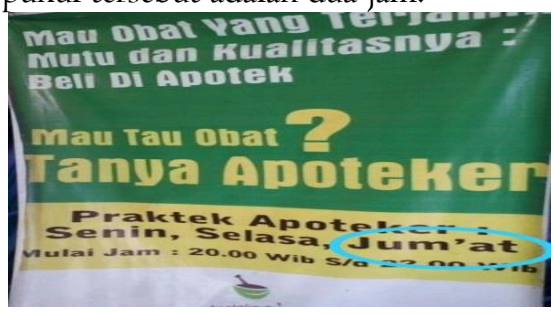

"Jum'at" pada penulisan spanduk di atas menunjukan penulisan tidak baku karena kata “juma'at di adopsi dari Bahasa Arab dan sudah dibakukan menjadi "jumat" tanpa menggunakan tanda baca petik tunggal namun pelafalan yang berbeda dengan penulisan sedikit berbeda. Pelafalannya menggunakan tanda trema agak didengungkan.

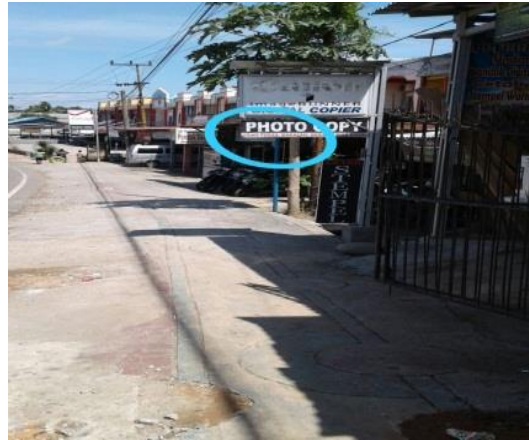

Penulisan kata tidak baku di atas "photo copy" masih banyak yang menggunakan padahal kata baku dari "photo copy" adalah "fotokopi". Penulisan kata "fotokopi" digabung sesuai dengan aturan dari Kamus Besar Bahasa Indonesia dan Tata Bahasa Baku dalam Bahasa Indonesia. Di Kota Bengkulu sebagian besar masih menggunakan bentuk kata tidak baku pada penulisan fotokopi tersebut.

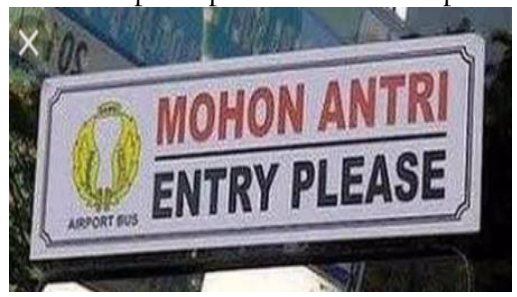

Gambar di atas terdapat dua bahasa yang digunakan. Hal ini boleh saja karena bahasa Inggris adalah bahasa dunia dalam berkomunikasi. Dengan demikian, jika terdapat turis atau wisatawan yang berlibur atau keperluan lainnya dapat dipahami dengan baik sebaagai petunjuk. Untuk melihat dari kebakuan penulisan kata "antri" di atas bentuk bakunya adalah "antre”."Antri” adalah pelafalan yang setiap hari digunakan masyarakat.

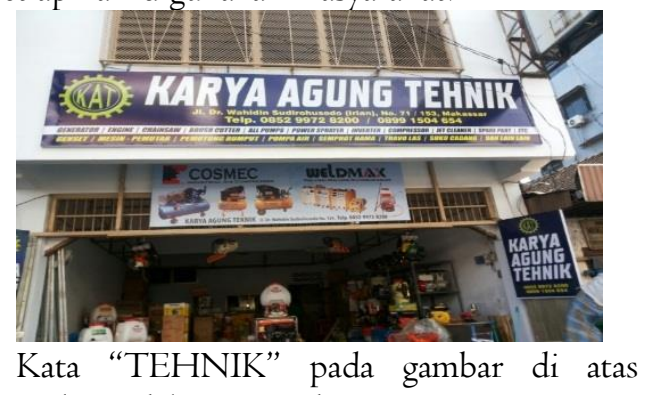
terlihat jelas tidak sesuai dengan KBBI. Namun, pemilik toko tetap saja mengggunakan tanpa mengetahui latar belakang tulisan tersebut apakah sesuai dengan Ejaan yang Disempurnakan atau tidak. Untuk itu, perlu adanya pemahaman terhadap penulisan agar terhindar dari penulisan tidak baku. Perbaikan dari kata "TEHNIK" bentuk bakunya adalah "Teknik". 


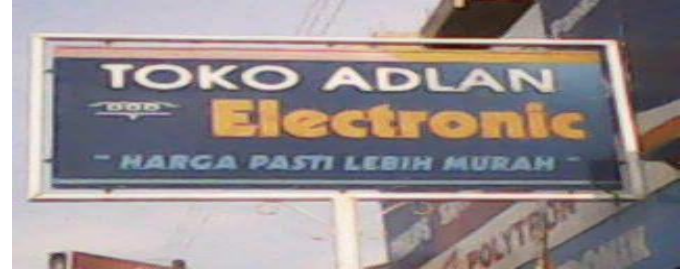

Jika dilihat penulisan pada gambar di atas lebih teliti lagi, maka didapat penulisan kata tidak baku. Terdapat tiga huruf dari ketiga kata tersebuttampak jelas salah satunya tidak baku yaitu "Electronic". Kata ini seharusnya ditulis "Elektronik"sesuai dengan kata baku yang ditetapkan pada Pedoman Ejan Bahasa Indonesia. Sebagian tulisan ini terdapat di tempat-tempat umum atau jalan besarsehingga banyak masyarakat yang melewati jalan tersebut dan membacanya. Dengan begitu, asumsi masyarakat penulisan "Electronic" adalah baku padahal sudah dijelaskan dalam aturan yang baku adalah "Elektronik".

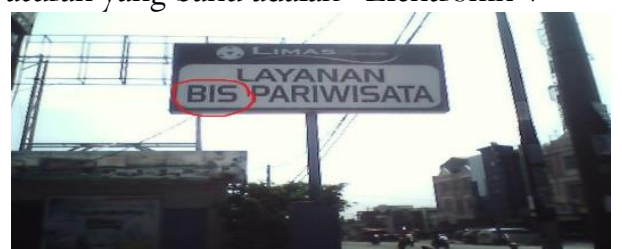

Penulisan di atas terdapat kata "bis" secara penerapan kaidah ejaan yang baik dan benar kata "bis" termasuk kata tidak baku. Kata "bis" bentuk bakunya adalah "bus". Hal ini sudah dijelaskan ke dalam Kamus Besar Bahasa Indonesia. Penulisan kata ini masih terdapat pada loket-loket pemberangkatan bus. Dengan demikian menjadi permasaahan bersama jika penulisan kata ini terus menerus di abaikan.

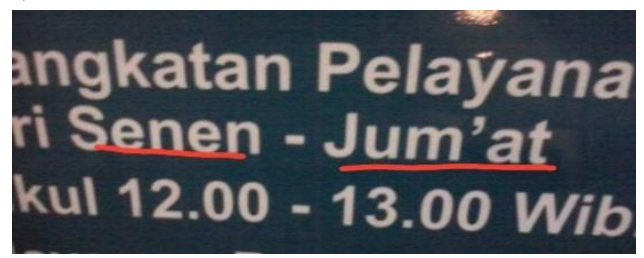

Kata "senen dan jum'at" di atas adalah kata yang di adopsi dari bahasa Arab. Untuk penulisan yang baku atau standarnya adalah "senin" dan jumat". Untuk pelafalan "senin" sesuai dengan tulisannya sedangkan "jumat" pelafalannya menggunakan tanda trema suara pelafalan di dengungkan. Sesuai dengan ketentuan yang berlaku bahwa penulisan tersebut tidaklah baku. Untuk menghindari kata tidak baku dapat berpedoman kepada Pedoman Ejaan Umum Bahasa Indonesia.

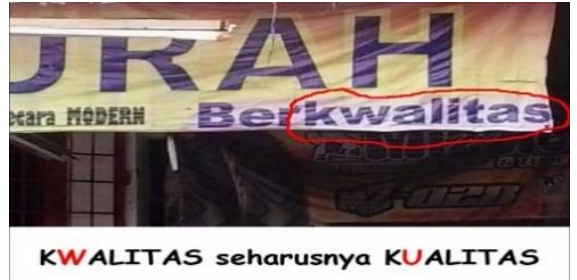

Kata "berkwalitas" paada gambar di atas sudah jelas menunjukan kata tidak baku tetapi tetap digunakan oleh pedagangnya. Kata dasar "berkwalitas" pada gambar di atas adalah "kwalitas". Menurut Kamus Besar bahasa Indonesia bentuk baku kata kwlitas yaitu "kualiitas". Selama ini sebagian masyarakat umum tidak mengetahui penulisan kata tersebut sehingga dalam penggunaannya menyalahi aturan yang baku.

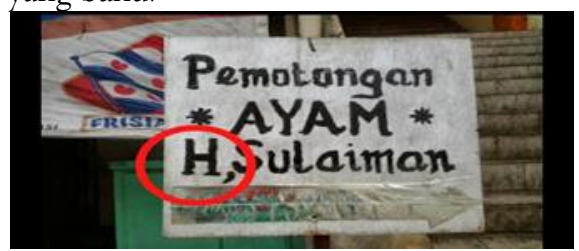

Penulisan nama pun harus mengikuti aturan yang baku. Jika dalam penulisan nama beserta gelar tidak menurut Pedoman Ejaan Umum Bahasa Indonesia maka bentuk bakunya adalah nama gelar diakhiri tanda titik dan diikuti nama orang (jika gelar di depan nama orang). Gelar yang diakui adalah gelar akademik yang diperoleh melalui jalur akademik untuk "haji" bukanlah gelar akademik. Selama ini masih terdapat penulisan "haji" ditulis dan diikuti nama orang. Jika "haji”" adalah gelar, pada gambar di atas adalah tidak baku. Untuk menulis gelar diakhiri tanda titik.

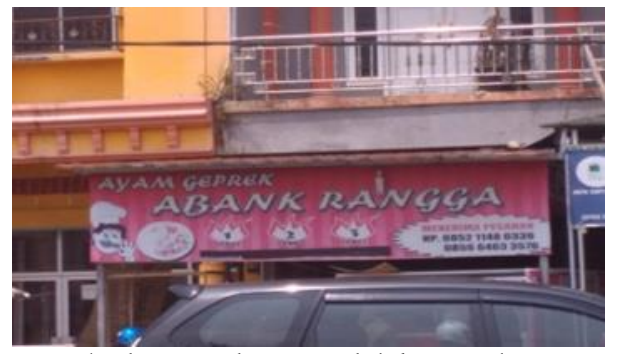

Merek dagang di atas adalah penulisan yang tidak baku terdapat kata "abank" seharusnya adalah "abang". "abang" artinya adalah kakak yang dituakan. Penulisan tersebut untuk membuat menarik pengunjung. Alasan tersebut sebagian dikemukakan oleh penjual. 


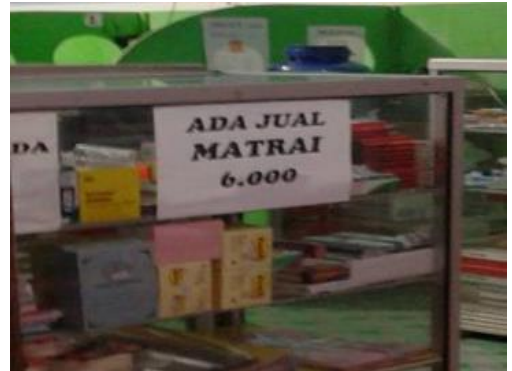

Penulisan "matrai" pada gambar di atas tidaklah baku. Bentuk bakunya sesuai dengan Pedoman Ejaan Umum Bahasa Indonesia adalah "materai". Jika masyarakat sudah mengetahui penulisan materai yang sebenarnya, dengan ini kemungkinan kecil penulisan tidak baku akan terhindar.

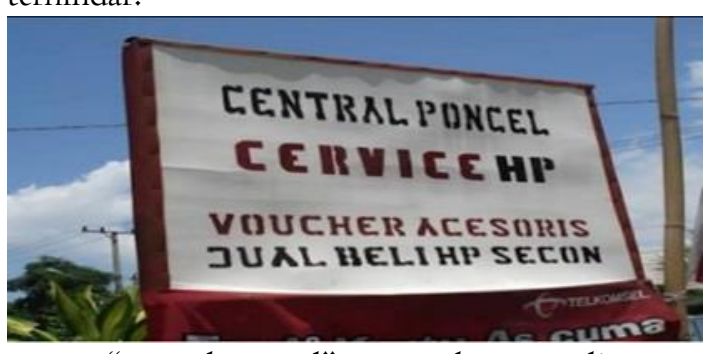

"central poncel" merupakan penulisan yang tidak baku di dalam aturan baku bahasa Indonesia. Central artinya pusat dan poncel artinya telepon genggam. Dalam penulisan kata terdapat pada sebuah papan nama di pinggir jalan raya yang secara umum dilihat dan dibaca sebagian masyarakat yang melewati jalan tersebut.Kedua kata tidak baku ini tidak mengikuti aturan sesuai dengan Pedoman Ejaan Umum Bahasa Indonesia. Perbaikan kata "Central poncel" menjadi "Pusat Telepon Genggam”. Dengan demikian, secara perlahan jika sebagian masyarakat menggunakan kata baku sesuai dengan aturan Pedoman Ejaan Bahasa Indonesia maka akan terbiasa.

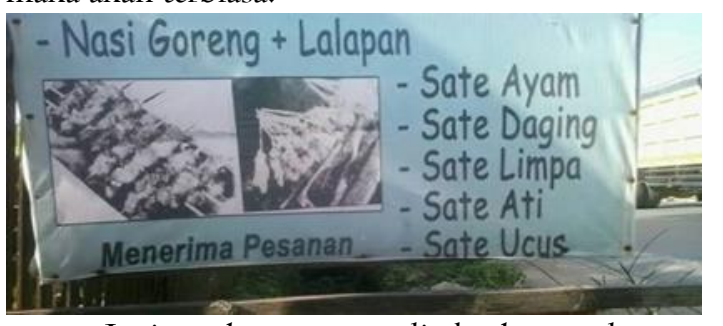

Jenis makanan yang disebutkan pada papan nama di atas masih terdapat kata tidak baku yakni "Sate ati" dan Sate Ucus". Dalam penulisan kedua kata "ati" dan "ucus" seharusnya ditulis yang benar adalah "hati” dan "Usus".Kata "ati” hamper sama dengan pelafalan yang biasa digunakan dalam percakapan sehari-hari.

Pada penelitian sebelumnya terdapat pada artikel jurnal dengan judul Penggunaan Bahasa Indonesia pada Media Ruang Publik di Pekan Baru oleh Fatmahwati (2018) yakni tentang Fenomena penggunaan bahasa pada ruang publik di Kota Pekanbaru didominasi oleh penggunaan bahasa asing dan bahasa Indonesia yang tidak sesuai kaidah. Kesalahan penulisan bahasa Indonesia yang ditemukan mencakup kesalahan ejaan, kata, tanda baca, unsur serapan, pilihan kata, dan kalimat. Faktor-faktor yang memengaruhi kedua kondisi tersebut adalah responden tidak mengetahui adanya landasan hukum (undang-undang) penggunaan bahasa Indonesia di ruang publik dan tidak mengetahui kaidah bahasa Indonesia yang baik dan benar. Selain itu, responden bersikap positif terhadap bahasa asing dan cenderung bersikap negatif terhadap bahasa Indonesia.

Adapun penelitian yang sama membahas tentang kata baku oleh Muriyani (2013) yakni berjudul Analisis Kesalahan Kata baku dan Makna Kata dalam Menulis Karangan Pengalaman Pribadi pada Siswa Kelas VII Sekolah Menengah Pertama Negeri 4 Kota Tanjungpinang. Penelitian ini bertujuan untuk mengetahui kesalahan siswa dalam penggunaan kata baku, makna denotatif dan makna konotatif dalam Menulis Karangan Pengalaman Pribadi paada Siswa Kelas VII Sekolah Menengah Pertama Negeri 4 Kota Tanjungpinang. Metode yang digunakan dalam penelitian ini adalah metode analisis deskripsi kualitatif. Teknik pengumpulan data yang digunakan adalah teknik observasi dan tes. Berdasarkan hasil penelitian di lapangan, penggunaan kata baku dan makna kata pada siswa kelas VII Sekolah Menengah pertama Negeri 4 Kota Tanjungpinang dalam menulis karangan pengalaman pribadi adalah 53,2 tergolong kurang.

Selanjutnya, penelitian oleh Supriadin (2016) dengan judul Identifikasi Penggunaan Kosakata Baku dalam Wacana Bahasa Indonesia pada Siswa Kelas VII di SMP Negeri I Wera Kabupaten Bima. Penelitian ini membahas tentang penyebab terjadinya penggunaan kosakata tidak baku yaitu adanya tukar-menukar huruf dalam kata, pelesapan huruf, dan penambahan huruf pada kata.

Bahasa Indonesia merupakan bahasa standar dan sebagai acuan untuk digunakan sehari-hari dalam masyarakat serta digunakan dalam percakapan resmi. Bahasa yang tidak baku, yaitu bahasa yang digunakan dalam percakapan sehari-hari. Bahasa terdiri atas beberapa tataran gramatikal antara lain kata, frase, klausa, dan kalimat. Oleh karena itu, sejumlah kata dalam Bahasa Indonesia harus dipahami dengan baik, agar ide dan pesan seseorang mudah dimengerti. Dengan demikian, kata-kata yang digunakan untuk berkomunikasi harus dipahami dalam konteks alinea dan wacana. Kata sebagai unsur 
bahasa, tidak dapat dipergunakan dengan sewenangwenang. Akan tetapi, kata-kata tersebut harus digunakan dengan mengikuti kaidah-kaidah yang benar. Sudah selayaknyalah kalau semua orang/warga negara Indonesia mempunyai sikap positif terhadap bahasa yang mereka gunakan. Dalam berkomunikasi menggunakan bahasa Indonesia baik tulisan maupun lisan. Haruslah mempertimbangkan tepat tidaknya dalam penggunaan kosakata. Kita sebagai warga negara Indonesia harus mempunyai sikap seperti itu karena siapa lagi yang harus menghargai bahasa Indonesia selain warga negaranya. Kita, sebagai bangsa Indonesia harus bersyukur, bangga, dan beruntung karena memiliki bahasa Indonesia sebagai bahasa nasional dan bahasa Negara. Menggunakan bahasa baku terutama di dunia pendidikan memang sudah seharusnya diterapkan, karena hal itu akan menunjukan bahwa siswa atau generasi selajutnya tidak lupa dengan bahasanya sendiri.

Pada pembahasan di atas masih terdapat penulisan-penulisan tidak sesuai dengan aturan penulisan yang baku. Tiga dari beberapa penulisan kata tidak baku yang didapat oleh penulis sudah menjadi sampel dalampenelitian ini diantaranya terdapat penulisan kata "photo copy", "antri”, "bis".Ketiga penulisan ini merupakan penulisan kata tidak baku yang tidak sesuai aturan Pedoman Ejaan Umum Bahasa Indonesia. Penulisan yang baku pada kata "photo copy" seharusnya menjadi bentuk bakunya adalah "foto kopi". Penulisan yang baku pada kata"antri" seharusnya "antre" sedangkan Penulisan yang baku pada kata "bis" seharusnya "bus".Ketiga penulisan ini menjadi contohpenulisan kata tidak baku yang sebaiknya tidak digunakan pada masyarakat jika akan memberikan nama merek dagang toko dan jasa. Untuk menghindari penulisan kata tidak baku ini dengan langkah meminta arahan kepada pemerhati bahasa atau dapat dilihat pada Kamus Besar Bahasa Indonesia.Bagi masyarakat umum yang membaca tulisan tersebut menganggap hal biasa saja karena tidak ada kepentingan yang khusus berbeda dengan pemerhati bahasa yang semakin lama semakin prihatin dengan keadaan.

\section{Simpulan}

Berdasarkan teori tentang ketidakbakuan ditandai dengan penyimpangan diantaranya: penggunaan kata, ejaan, dan susunan kalimat. Berdasarkan dari hasil penelitian yang diperoleh dan dikaitkan dengan teori ketidakbakuan didapat berupa kata dan ejaan. Hal ini dilihat dari para pemilik toko dan jasa menulis merek dagangnya tidak berdasarkan kata baku yang sudah ditetapkan dengan standar PEUBI (Pedoman Ejaan Bahasa Indonesia). Hasil dari penelitian ini didapat bahwa penulisan kata tidak baku masih terdapat di tempattempat umum, sehingga berdampak kepada masyarakat terutama pelajar, mahasiswa, para tokoh pendidik, dan lainnya. Masyarakat secara luas masih belum dapat membedakan dan belum memahami penulisan kata tidak baku yang sebaiknya tidak digunakan. Akan tetapi, masyarakat berkesimpulan menetapkan penulisan kata dari kehidupan seharihari. Ketika penulisan kata tidak baku tersebar secara luas maka penulisan kata terancam tidak diketahui oleh pemakai bahasa. Beberapa penulisan kata tidak baku yang didapat pada lokasi yang berbeda yakni Praktek, Jam, Jum'at, Photo Copy, Antri, Tehnik, Electronic, Bis, Senen-Jumat, Berkwalitas, H, Sulaiman, Matrai, Abank Rangga, Central Poncel, Sate Ati, dan Sate Ucus.

\section{Persantunan}

Penelitian ini dapat terlaksana dengan baik karena dukungan dari berbagai pihak diantaranya pihak Yayasan Dehasen Bengkulu, Rektor Universitas Dehasen Bengkulu, Ketua LPPM Universitas Dehasen Bengkulu, Dekan Fakultas Ekonomi, Ketua Program Studi Manajemen, rekanrekan dosen terutama di Fakultas Ekonomi. Kemenristek Dikti dan L2Dikti Wilayah II yang memberikan kesempatan kepada penulis untuk mengembangkan potensi dalam Penelitian Dosen Pemula.

\section{Daftar Pustaka}

Alwi Hasan, dkk. 2003. Tata Bahasa Baku Bahasa Indonesia. Jakarta: Balai Pustaka.

Akhadiah, Sabarti, dkk. I99I. Pembinaan Kemampuan Menulis Bahasa Indonesia. Jakarta: Erlangga.

Arikunto, Suharsimi. 2010. Prosedur Penelitian. Jakarta: Rineka Cipta.

Danardana, Agus Sri. 20II. Anomali Bahasa. Pekanbaru: Palagan Press.

Fatmahwati. 2018. "Penggunaan Bahasa Indonesia pada Media Ruang Publik

di Kota Pekanbaru”. Suar Betang. Vol. 13 No. 2 : I3I-I44.

Hs. Widjono. 2007. Bahasa Indonesia: Mata Kuliah Pengembangan Kepribadian di Perguruan Tinggi.Jakarta: PT Grasindo.

Muriyani. 2013. “Analisis Kesalahan Kata Baku dan Makna Kata dalam Menulis Karangan Pengalaman Pribadi pada Siswa Kelas VII Sekolah Menengah Pertama Negeri 4 Kota Tanjungpinang”. Skripsi. Tanjungpinang: 
Fakultas Keguruan dan Ilmu Pendidikan, Universitas Maritim Raja Ali Haji.

Muslich, Masnur. 2010. Bahasa Indonesia pada Era Globalisasi. Jakarta: PT Bumi Aksara.

Putrayasa, Ida Bagus. 2007. Kalimat Efektif : Diksi, Struktur, dan Logika. Bandung: Refika Aditama.

Rahardi, Kunjana. 2009. Bahasa Indonesia untuk Perguruan Tinggi. Jakarta: Erlangga.

Indonesia untuk Karang-Mengarang. Jakarta: Erlangga.

Rodiyah, dkk. 20II. Bahasa Indonesia: untuk Mahasiswa Kesehatan. Yogyakarta: Gosyen.

Supriadin. 2016. "Identifikasi Penggunaan Kosakata Baku dalam Wacana Bahasa Indonesia pada Siswa Kelas VII di SMP Negeri I Wera Kabupaten Bim”. JIME. Vol 2 No. 2: I50I6I.

Soedjarwo. 2007. Beginilah menggunakan Bahasa Indonesia. Yogyakarta: Gadjah Mada University Press.

Sugihastuti dan Siti Saudah. 2016. Buku Ajar Bahasa Indonesia Akademik.Yogyakarta: Pustaka Pelajar.

Sukardi. 2011. Metodologi Penelitian Pendidikan. Jakarta: Bumi Aksara. 